«Системні технологіï» 5 (124) 2019 «System technologies»

DOI 10.34185/1562-9945-5-124-2019-14

УДК 629.7.036

С.С. Василів, Н.С. Прядко

\title{
КЛАСИФІКАЦІЯ СХЕМ ФОРСУНОЧНИХ ГОЛОВОК РОТАЦІЙНОГО ДЕТОНАЦІЙНОГО РАКЕТНОГО ДВИГУНА
}

Анотація. Стаття присвячена проблемам змішування компонентів палива в камерах згорання детонаційних ракетних двигунів. Основною ідеєю, що спонукає вчених до пошуків у цьому напрямку, є вищий термодинамічний коефіцієнт корисної дії детонації в порівнянні зі звичайним горінням з дозвуковими швидкостями. Також детонаційний процес може відбуватися при відносно низьких значеннях тисків компонентів палива, що дозволяє відмовитись від важких систем живлення, а використати просту витискувальну систему подачі. Відомі експериментальні дослідження використовуються для подальших наукових пошуків шляхів вирішення проблем із сумішоутворенням.

Для оцінки ефективності процесу змішування використовується комп'ютерне моделювання. Визначено масштаб турбулентності в різних схемах форсуночних головок. Проведено класифікацію схем в порядку збільшення масштабу турбулентності i, відповідно зниження ефективності двигуна. Запропоновано перехід до використання форкамер 3 попереднім перемішуванням компонентів палива в одному об'ємі і детонацією їх суміші в іншому.

Ключеві слова: ракетний двигун, детонація, форсуночна головка

Вступ. В детонаційному ракетному двигуні відбувається багато процесів, зв’язаних з течією газів. Наприклад, впорскування та змішування компонентів, запалювання суміші, ініціація та розповсюдження детонаційної хвилі всередині камери згоряння, розширення продуктів детонації в надзвуковому соплі. Оскільки ці процеси взаємозалежні, впливають один на одного, то всі вони в певній мірі мають значення на забезпечення енергетичної ефективності детонаційного двигуна, яка виражається питомим імпульсом. Напрямки оптимізації функціонування детонаційних двигунів окрім пошуку геометричних параметрів камери згорання, в якій може відбуватись детонація, та паливної композиції, включають також і дослідження характерного часу, за який відбувається

(C) Василів С.С., Прядко Н.С., 2019 
процес сумішоутворення. Однак більшість досліджень передбачають, що детонація відбувається в ідеальній детонаційній камері, тобто в такій, де відбувається миттєве перемішування компонентів. На практиці паливо та окислювач вводяться в детонаційну камеру як окремі струмені з різними умовами впорскування. Тому змішування не є миттєвим. Окрім параметрів, які регулюють будь-який процес горіння, є й інші, які дуже важливі для розробки моделі двигуна. Ці параметри включають межі детонації, енергію ініціації та товщину зони реакції. Знання структури детонаційних хвиль, а також швидкості хімічних реакцій необхідні для кількісної оцінки параметрів детонаційного двигуна [1].

Аналіз попередніх публікацій. Для практичних детонаційних двигунів, що в якості окислювача використовують повітря, принципове значення має детонація сумішей вуглеводневих палив з ним. Мінімальні розміри комірки детонації їх та енергія активації, необхідної для ініціювання детонації, зазвичай дуже великі [2]. Окрім того, структура потоку суміші перед проходженням детонаційного фронту має велике значення для повноти протікання хімічних реакцій i, відповідно, для енергетичних характеристик двигуна в цілому [3].Змішування різних газоподібних потоків може передбачати безліч процесів і явищ. Паливо і окислювач змішані в молекулярному масштабі, можуть сприяти утворенню хімічних реакцій і пов'язаного з цим виділення тепла. Тому актуальною є задача забезпечення мінімального часу на перемішування компонентів палива та рівномірний їх розподіл по тому об’єму камери згорання, де відбувається детонація [1].

Метою роботи є комп’ютерне моделювання течії в камері згорання біля форсуночної головки ротаційного детонаційного ракетного суміші водню та повітря.

Змішування газоподібного палива відбувається за рахунок дифузії і конвекції потоків. В турбулентних потоках біля форсуночної головки і відбувається перемішування. Далі суміш заповнює об’єм камери згорання допоки детонаційний фронт не пройде через неї. При цьому спостерігається значне підвищення тиску і запирання форсунок: компоненти палива не потрапляють в камеру згорання. За детонаційним фронтом руха- 
«Системні технології» 5 (124) 2019 «System technologies»

ється хвиля розрідження. Тиск знижується і форсуночна головка знову подає компоненти палива в камеру згорання [4].

Для газів нестаціонарна дифузія на межі їх контакту визначатиметься законом Фіка [5]:

$$
m=D \frac{d c}{d x} \cdot S \cdot \tau_{\partial}
$$

де $m$ - маса порції суміші;

$D$ - коефіцієнт дифузії;

$S$ - площа поверхні контакту компонентів палива;

$\tau$ 一 - час дифузійного вирівнювання концентрацій компонентів;

c -концентрація компоненту;

А масштаб турбулентності $x$ рівний:

$$
x=\left(D \tau_{\partial}\right)^{\frac{1}{2}}
$$

Час дифузії порції компонентів $m$ з висотою шару свіжої суміші $h$ зв’язані залежністю[4]:

$$
h=u \cdot \tau_{\partial}
$$

В роботі [6] було показано, що період, за який проходить детонаційний фронт повне коло, менший від часу $\tau$, за який відбувається вирівнювання концентрацій компонентів, більш ніж в 2 рази. В продовження цієї роботи проведемо моделювання течії повітря і водню в різних схемах форсуночних головок. Геометричні розміри області течії взяті 3 [1].

Розглядається 4 варіанти схем форсуночних головок:

1) 3 розгінною ділянкою окислювача та струменевою форсункою пального [7] ;

2) 3 кишенею та виступом;

3) з вихровим турбулізатором та щілинною форсункою;

4) з вихровим турбулізатором та струменевою форсункою;

Варіанти 3 та 4 описані в [8] та являють собою щілинну форсунку окислювача, поверхні якої виконані з гребенями під кутом до напрямку потоку, причому з направленням в різні сторони. Таким чином, в шарі газу, який ближче до поверхні, виникають дотичні напруження, а потік посередині залишається незмінним. Це викликає утворення вихору, який 
«Системні технології» 5 (124) 2019 «System technologies»

взаємодіє зі струменем пального, що витікає з форсунки, розміщеної перпендикулярно форсунці окислювача.

Комп’ютерне моделювання здійснювалось в прикладному програмному пакеті SolidWorks. Його метою було визначення масштабу турбулентності для кожного варіанту. Результат моделювання проілюстрований на рис. $1-4$.

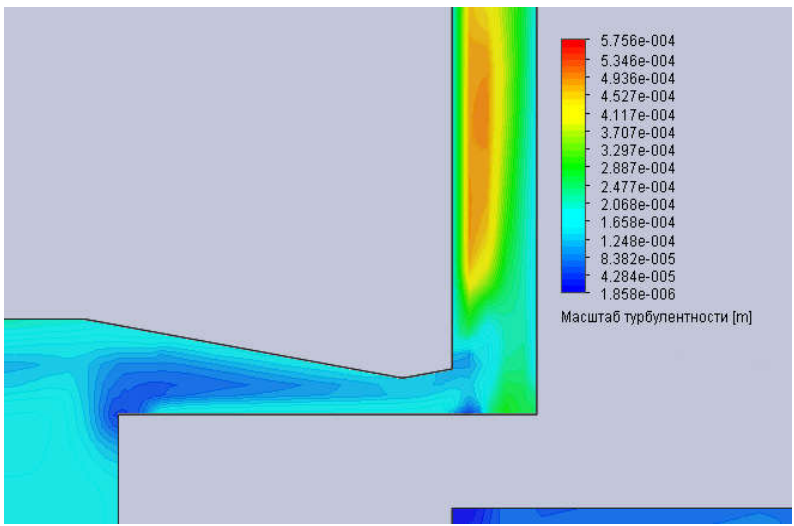

Рисунок 1 - Масштаб турбулентності для I варіанту

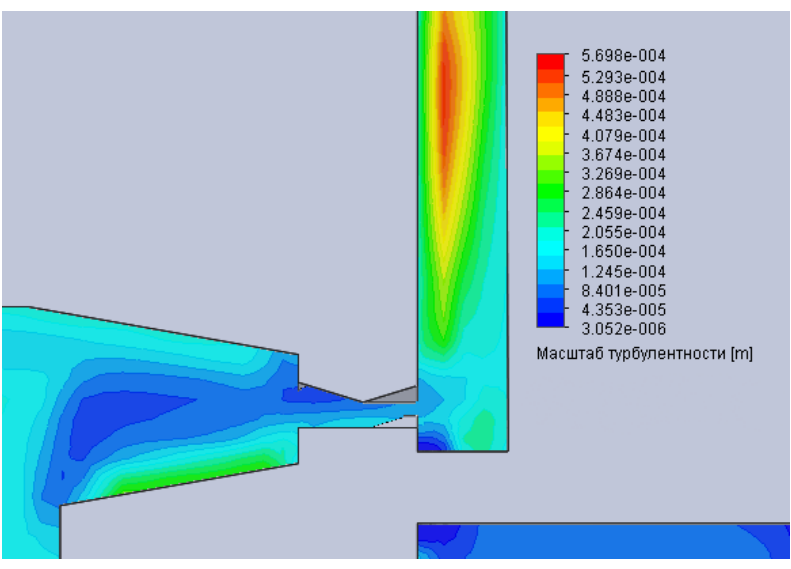

Рисунок 3 - Масштаб турбулентності для III варіанту

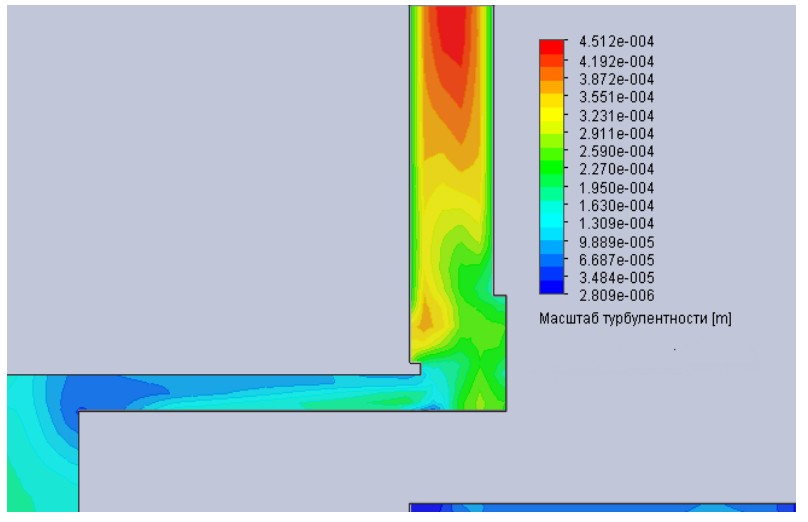

Рисунок 2 - Масштаб турбулентності для II варіанту

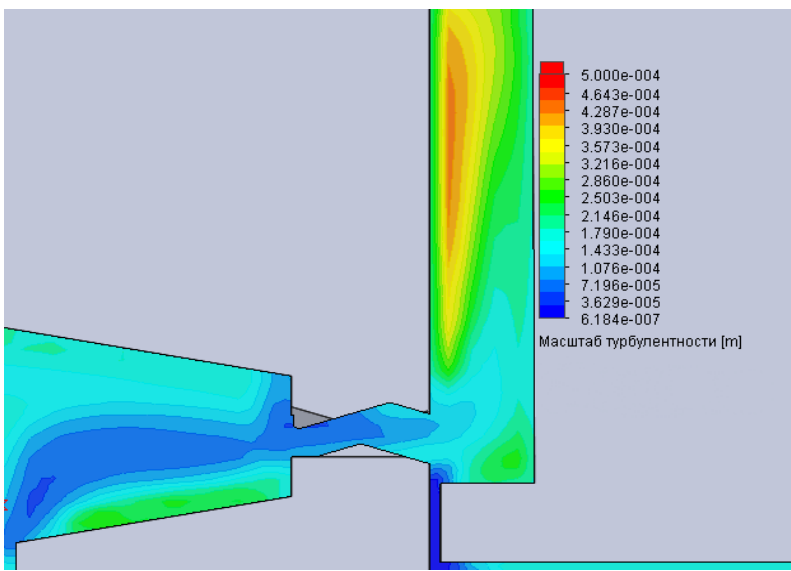

Рисунок 4 - Масштаб турбулентності для IV варіанту

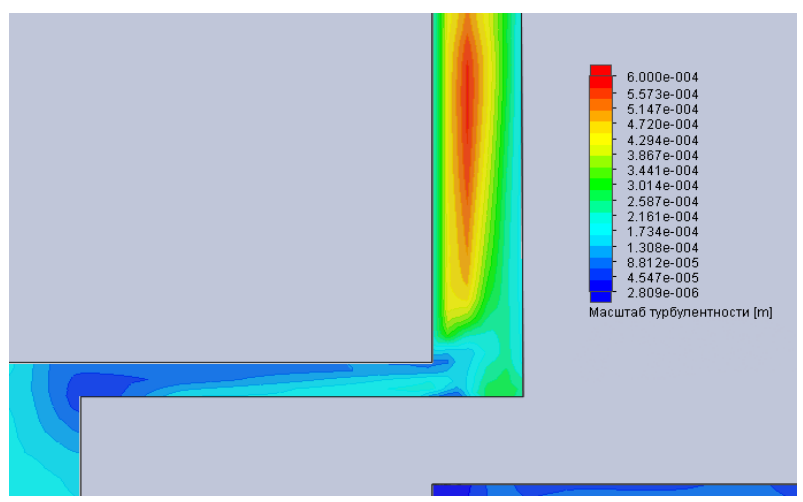

Рисунок 5 - Масштаб турбулентності для базового варіанту [6]. 
«Системні технології» 5 (124) 2019 «System technologies»

3 ілюстрацій можна розробити класифікацію схем за зростанням масштабу турбулентності в такому порядку:1) варіант 3 кишенею та виступом; 2) варіант з вихровим турбулізатором та щілинною форсункою; 3) варіант з розгінною ділянкою окислювача та струменевою форсункою пального; 4) варіант з вихровим турбулізатором та струменевою форсункою. На рис. 5 проілюстровано графік масштабу турбулентності [6] для базового варіанту [9], який в наведеному порядку буде 5-тим.

Всі варіанти, що були промодельовані мають менший масштаб турбулентності в порівнянні з базовим. Це значить, що час проходження дифузії в повітряно-водневій суміші буде меншим, а відтак і хімічні реакції за детонаційним фронтом протікатимуть з більшою повнотою. Це позитивно відображається на енергетичних характеристиках ротаційного детонаційного ракетного двигуна. Однак варто зауважити, що ці схеми також не задовольняють умові рівності часу дифузійного вирівнювання концентрацій з періодом проходження детонаційного фронту, тому більш ефективним може бути перехід до форкамери, де змішування компонентів палива відбувається в одному об’ємі, а детонація готової суміші в іншому.

Висновки. Проведено комп’ютерне моделювання течії повітря та водню в плоскій моделі камери згорання в зоні форсуночної головки ротаційного детонаційного ракетного двигуна. Визначено масштаб турбулентності в заданих вихідних параметрах експерименту, що проводився американськими вченими. Класифіковано схеми форсуночних головок в порядку зростання масштабу турбулентності i, відповідно, зниження ефективності ротаційного детонаційного ракетного двигуна, що використовуватиме кожну з них. Обгрунтовано перехід до форкамер попереднього перемішування компонентів палива.

\section{ЛІТЕРАТУРА / ЛИТЕРАТУРА}

1. Василів С.С. Експериментальні дослідження течії газу в плоскій моделі ротаційного детонаційного ракетного двигуна / С. С. Василів, В. О. Грушко, М. Ю. П’ясецький // Журнал «Технічна механіка» №1, 2017p. - ITM НАНУ і ДКАУ - Дніпро - С. 47 - 56.

DOI: https://doi.org/10.15407/itm2017.01.047. 
«Системні технологіï» 5 (124) 2019 «System technologies»

2. М. Нетлетон Перевод с английского под редакцией Л. Г. Гвоздевой. Детонация в газах. М: Мир. 1989. - 280с.

3. Импульсные детонационные двигатели / под ред. д.ф.-м.н. С.М. Фролова - М.: ТОРУС ПРЕСС, 2006. - 592с.

4. Быковский Ф.А. Непрерывная спиновая детонация / Ф.А Быковский, С.А. Ждан - Рос. акад. наук, Сиб. отд-ние, Институт гидродинамики им. М.А. Лаврентьева. - Новосибирск: Изд-во СО РАН, 2013. - 423с.

5. Тимошенко В. И. Теоретические основы технической газовой динамики. Справочное пособие / В. И. Тимошенко, - Киев, Наукова думка, 2013. -409 c.

6. Vasyliv S.S. Computer Simulation of the Fuel Component Mixing Process in the Combustion Chamber of Detonation Rocket Engine / S.S. Vasyliv // «Системні технології» 6(118), 2018p. - С. 114 - 121.

7. Blaine R. Bigler, John W. Bennewitz, Stephen A. Danzyk, William A. Hargus Jr. Injector Mixing Effects in Rotating Detonating Rocket Engines / American Institute of Aeronautics and Astronautics. Conference Paper 2019 - 13p. DOI: 102514/6.2019-3869

8. Пат. на винахід 111996 Україна, МПК F02К9/00 Детонаційний рідинний ракетний двигун / Василів С.С., Коваленко М.Д.; заявник і патентоволодар ІТМ НАНУ і ДКАУ - а 2014 10645; заявл. 07.07. 2014; опубл. 11.07.2016, Бюл. №13 - 4ст.

9. Shank Jason C. Development and testing of a rotating detonation engine run on hydrogen and air: thesis, presented to the Faculty Department of Aeronautics and Astronautics Graduate School of Engineering and Management Air Force Institute of Technology Air University Air Education and Training Command In Partial Fulfillment of the Requirements for the Degree of Master of Science in Aeronautical Engineering / Jason C. Shank. - USAF, 2012. $-70 \mathrm{p}$.

\section{REFERENCES}

1. Vasyliv S.S. Experimental studies of gas flow in a plane model of a rotary detonation rocket engine / S.S. Vasyliv, V.O. Hrushko, M. Yu. Piasetsky // Journal of Technical Mechanics.- №1, 2017. - P.47 - 56. DOI: https://doi.org/10.15407/itm2017.01.047. 
«Системні технологіï» 5 (124) 2019 «System technologies»

2. M. Netleton. Detonation in gas.- M: Mir. 1989. - 280 p.

3. Impulse detonation motors/ Ed. S.M. Frolov - M.: TORUS PRESS, 2006. $592 \mathrm{p}$.

4. Bykovsky FA Continuous spin detonation / F.A. Bykovsky, S.A Zhdan - Ross. Acad. of Sciences, Sib. Department of Hydrodynamics. MA. Lavrentyev. - NoVosibirsk: Published in SB RAS, 2013. - 423p.

5. Tymoshenko V.I. Theoretical foundations of technical gas dynamics. A reference manual / V.I. Tymoshenko, - Kiev, Naukova Dumka, 2013. - 409p.

6. Vasyliv S.S. Computer Simulation of the Fuel Component Mixing Process in the Combustion Chamber of Detonation Rocket Engine / S.S. Vasyliv // System technology. - N 6(118).- Dnipro, 2018.- P. 114 - 121

7. Blaine R. Bigler, John W. Bennewitz, Stephen A. Danzyk, William A. Hargus Jr. Injector Mixing Effects in Rotating Detonating Rocket Engines / American Institute of Aeronautics and Astronautics. Conference Paper 2019 - 13p. DOI: 102514/6.2019-3869

8. Invent. Pat. 111996 Ukraine Detonation Liquid Rocket Engine/ Vasyliv S.S, Kovalenko M.D. - publ. 11.07.2016, Bul. N 13.

9. Shank Jason C. Development and testing of a rotating detonation engine run on hydrogen and air: thesis, presented to the Faculty Department of Aeronautics and Astronautics Graduate School of Engineering and Management Air Force Institute of Technology Air University Air Education and Training Command In Partial Fulfillment of the Requirements for the Degree of Master of Science in Aeronautical Engineering / Jason C. Shank. - USAF, 2012. $-70 \mathrm{p}$.

Received 19.11.2019. Accepted 22.11.2019.

\section{Классификация схем форсуночных головок ротационного детонационного ракетного двигателя}

Статья посвящена влиянию смесеобразования в форсуночных головках ротационных детонационных ракетных двигателях на процесс детонации. Актуальность работ ученых в этом направлении обусловлена высоким термодинамическим коэффициентом полезного действия детонации по сравнению с обычным горением с дозвуковыми скоростями. Кроме того, детонационный процесс может происходить при относительно низких значениях давления компонентов топлива, что позволяет отказаться от тяжелых систем питания, а использовать простую систему подачи выдавливанием.

Цель работы - компьютерное моделирование течения смеси водорода и воздуха в камере сгорания около форсуночной головки ротационного детонационного ракетного двигателя. Для оценки эффективности процесса смешивания используется компьютер- 


\section{«Системні технології» 5 (124) 2019 «System technologies»}

ное моделирование. Рассматривается пять вариантов схем форсуночных головок и для них проведено моделирование течения воздуха и водорода. Определен масштаб турбулентности для каждой схемы. Проведена классификация схем в порядке увеличения масштаба турбулентности и снижения эффективности двигателя. Предложен переход к использованию форкамер с предварительным перемешиванием компонентов топлива в одном объеме и детонацией их смеси в другом.

Classification of injection systems of a rotational detonation rocket engine

The article deals with the problems of mixing fuel components in combustion chambers for detonation rocket engines. The main idea that pushes scientists to search in this direction is the higher thermodynamic efficiency of detonation compared to conventional combustion at subsonic velocities. In addition, the detonation process can occur at relatively low pressure components of the fuel components, which allows abandoning heavy power systems and using a simple squeeze-roller feed system. Well-known experimental studies are used to further research ways to solve problems with blending.

The purpose of the work is computer flow simulation of hydrogen and air mixture in the combustion chamber near the nozzle head of a rotary detonation engine.

Computer simulation is used to evaluate the process efficiency of the fuel components mixing. Five variants of nozzle heads schemes are considered. Modeling of air and hydrogen flow in different nozzle head schemes is carried out. The turbulence scale for each scheme of the nozzle head is determined. The classification of circuits according to turbulence scale is conducted. It is shown that the classification corresponds decreasing of engine efficiency too. It is suggested to use antechamber with pre-mixing fuel components in one volume and detonation their mixture in another.

Василів Степан Степанович - молодший науковий співробітник, Інститут технічної механіки НАН України і ДКА України, м. Дніпро.

Прядко Наталія Сергіївна - провідний науковий співробітник Інституту технічної механіки НАН України і ДКА України, м. Дніпро, д.т.н., с.н.с.

Василив Степан Степанович - младший научный сотрудник, Институт технической механики НАНУ и ГАКУ.

Прядко Наталия Сергеевна - ведущий научный сотрудник, Институт технической механики НАН Украины и ГКА Украины, д.т.н., с.н.с.

Vasyliv Stepan Stepanovich - Junior Researcher, Institute of Technical Mechanics of the National Academy of Sciences of Ukraine and State Space Agency of Ukraine;

Pryadko Nataliya Sergeevna - Leading Researcher, Institute of Technical Mechanics of the National Academy of Sciences of Ukraine and State Space Agency of Ukraine, Doctor of Technical Sciences. 